\title{
EDUKASI NILAI GIZI IKAN MELALUI PELATIHAN PEMBUATAN MAKANAN OLAHAN BERBAHAN BAKU IKAN TONGKOL
}

\section{EDUCATION OF FISH NUTRITION VALUE THROUGH FOOD PROCESSING TRAINING USING MACKAREL-TUNA AS RAW MATERIAL}

\author{
Nanda Diniarti ${ }^{*}$,Nunik Cokrowati, Dewi Nur'aeni Setyowati, Alis Mukhlis \\ Program Studi Budidaya Perairan, Universitas Mataram \\ JI. Pendidikan No.37, Kota Mataram, Provinsi Nusa Tenggara Barat \\ ${ }^{*}$ Alamat korespondensi: nandadiniarti@unram.ac.id
}

(Tanggal Submission: 28 Januari 2020, Tanggal Accepted: 22 April 2020)

\begin{abstract}
ABSTRAK
Desa Batunampar merupakan salah satu desa pesisir yang $90 \%$ masyarakatnya merupakan nelayan. Tersediannya ikan konsumsi tidak dengan otomatis anak-anak di Desa batunampar mengkonsumsi ikan dan olahannya, sehingga dengan mudahnya anak-anak menyenangi mie dan makanan selingan/cemilan di warung. Ketidakberagamnya cemilan sehari-hari maka akan mendorong anak-anak mengkonsumsi cemilan yang tidak sehat yaitu berpengawet, kadar penyedap yang tinggi dan rendah nilai gizi. Maka dianggap perlu diadakan pilihan cemilan sehat yang bisa disediakan di rumah dari hasil tangkapan setempat. Dimana ikan tongkol merupakan tangkapan yang selalu ada di setiap musim dan melimpah. Ikan tongkol memiliki nilai gizi yang baik dan mudah untuk dikreasikan menjadi cemilan sehat dan disukai anak-anak. Tujuan kegiatan ini adalah memberikan edukasi gizi ikan dan memberikan keterampilan membuat makanan olahan dari ikan tongkol yaitu risoles dan presto tongkol. Metode yang digunakan dikegiatan ini adalah praktek langsung membuat risoles tongkol dan presto tongkol serta memberikan pengetahuan nilai gizi dan manfaat mengkonsumsi ikan. Penjelasan nilai gizi ikan dilakukan dengan cara memberikan penjelasan secara langsung dan memberikan contoh pada aktifitas sehari-hari. Kegiatan ini dilaksanakan di kantor desa Batunampar Selatan Kecamatan Jerowaru Kabupaten Lombok Timur. Peserta kegiatan sebanyak 28 orang terdiri dari ibu rumah tangga dan remaja putri. Olahan makanan yang dibuat adalah tongkol presto dan risoles tongkol. Risoles dan tongkol presto dipilih karena mudah dibuat, nilai gizi tinggi, dan memperlama masa simpan. Selain untuk menyediakan cemilan rumahan hasil produksi dapat dijual ke luar desa sehingga menambah pendapatan rumah tangga nelayan. Hasil pelaksanaan kegiatan ibu-ibu telah bertambah pemahaman tentang gizi ikan dan telah bisa mengolah dan mengkreasikan olahan berbahan dasar ikan tongkol.
\end{abstract}

Kata Kunci: batu nampar, ikan tongkol, presto, pelatihan, risoles.

\section{PENDAHULUAN}

Desa Batunampar Selatan terletak di Kecamatan Jerowaru Kabupaten Lombok Timur Provinsi Nusa Tenggara Barat (NTB) dengan luas wilayah $155 \mathrm{Ha}$ dan jumlah penduduk 2.525 jiwa atau 1.158 KK. Wilayah desa Batunampar terdiri atas dusun Batunampar, dusun Batunampar
Selatan dan dusun Temayang (PERDA Kabupaten Lombok Timur, 2001). Berdasarkan profil desa tahun 2013 Desa Batunampar Selatan berada pada ketinggian 0,30 meter dari permukaan laut, beriklim tropis yang memiliki curah hujan 1,128 $\mathrm{mm}$ pertahun dengan jumlah bulan hujan 2-4 bulan dalam setahun. Selain itu Desa Batunampar memiliki potensi lestari sebanyak 4557 ton/tahun 
ikan pelagis dan 6.843 ton/tahun ikan demersal (Anonim, 2002).

Bagian selatan Desa berbatasan dengan Samudera Hindia dimana potensi ekosistem yang ada di wilayah perairan tersebut dimanfaatkan sebagai potensi perikanan tangkap dan potensi perikanan budidaya. Potensi Budidaya perairan Laut yang dapat dikembangkan adalah budidaya kakap, kerapu, lobster, teripang, mutiara, kerangkerangan dan budidaya rumput laut. Mata pencaharian penduduk desa Batunampar selatan $90 \%$ adalah nelayan tangkap. Nelayan melakukan penangkapan ikan di perairan laut sekitar desa Batunampar dengan menggunakan perahu tanpa motor, Perahu Motor Tempel dan Kapal Motor (Cokrowati et al., 2016). Menurut data Dinas Kelautan dan Perikanan Kabupaten Lombok Timur Tahun 2003 jumlah perahu tanpa motor sejumlah 60 unit, Perahu motor 61 unit, dan kapal motor sejumlah 18 unit. Mereka menghasilkan hasil tangkapan ikan sesuai dengan musim ikan yang ada. Penangkapan ikan dilakukan dengan menggunakan jaring, jala, bagan tancap, bubu dan pancing. Jenis ikan yang tertangkap adalah Tongkol, Kerapu, baronang, kakap, teri, kembung, injong, pogot, ekor kuning dan kakatua.

Hasil tangkapan nelayan Batunampar Selatan lebih banyak dijual dalam bentuk segar. Keluarga nelayan juga mengolah dengan sederhana hasil tangkapan untuk konsumsi pribadi mereka atau dijual keluar desa. Ibu rumah tangga nelayan Ikan mengolah hasil tangkapan sebatas lauk sebagai teman makan nasi dan tidak terpikir untuk mengolah ikan atau hasil perikanan untuk makanan kecil/camilan untuk anak-anak balita dan usia sekolah. Kondisi tidak adanya pilihan sehat cemilan bagi anak-anak yang menyebabkan anakanak lebih menyenangimengkonsumsi mie instan dan cemilan yang dijual di warung-warung dan bagi ibu-ibu lebih mudah tanpa harus repot memasak.

Mie instan dan cemilan yang dijual di warung tidak memiliki gizi seimbang yang dibutuhkan untuk pertumbuhan anak sekolah. Mie instan dan cemilan juga mengandung pengawet serta penyedap yang berlebihan sehingga rasanya yang gurih membuat ketagihan anak-anak sekolah. Selain itu cemilan memiliki bentuk yang menarik yang semakin membuat anak-anak suka. Kesukaan anak-anak akan cemilan membuat mereka kekurangan gizi seperti yang dikemukakan oleh Hardinsyah (2001) dalam Tanziha (2009), menyebutkan bahwa tiga dari 10 anak balita Indonesia mengalami gizi kurang (KEP). Selanjutnya oleh Tanziha mengusulkan menyusun suatu perencanaan konsumsi pangan yang tepat yang memenuhi kebutuhan gizi, sesuai dengan kebiasaan konsumsinya dan serta terjangkau daya beli keluarga.

Anak-anak memerlukan gizi dari makanan sehari-hari dalam jumlah yang tepat dan kualitas yang baik. Gizi yang baik ini sangat penting untuk kelangsungan hidup anak, proses tumbuh kembang, pemeliharaan dan pemulihan kesehatan, serta untuk imunitas (Setyaningsih dan Agustini, 2014). Padahal di Desa Batunampar, ketersediaan ikan dari hasil tangkapan cukup memadai untuk memenuhi gizi masyarakat. Nampaknya anak-anak dan balita lebih menyukai mengkonsumsi mie instan dibanding dengan mengkonsumsi ikan segar. Pembuatan berbagai olahan hasil perikanan berbahan dasar ikan, diharapkan dapat meningkatkan konsumsi ikan pada anak dan balita sehingga terpenuhi kebutuhan gizinya. Olahan hasil perikanan itu diantaranya abon ikan, bakso ikan, nugget ikan dan camilan kerupuk ikan. Keterampilan pengolahan tersebut akan sangat bermanfaat jika diberikan kepada para gadis dan ibu rumah tangga sehingga mereka dapat berkontribusi pada tingkat kesehatan dan gizi anggota keluarganya.

Kemampuan dan keterampilan dalam mengolah hasil perikanan menjadi cemilan yang sehat dan menarik tidak dimiliki oleh ibu-ibu dan remaja putri desa Batunampar Selatan. Peran seorang ibu sangat penting atau di butuhkan dalam pemenuhan gizi pada anak. Seperti yang diungkapakan oleh Yendi et al. (2017). Pengetahuan dan keterampilan yang memadai seharusnya dimiliki oleh ibu sebagai modal dalam pemenuhan gizi bagi anak. Para ibu khususnya harus dapat membentuk pola makan anak, menciptakan situasi yang menyenangkan dan menyajikan makanan yang menarik untuk dapat memenuhi kebutuhan gizi anak-anaknya. Cemilan yang sehat dan menarik bisa diolah dari hasil tangkapan nelayan. Hasil tangkapan yang tiap musim ada ialah ikan tongkol. Ikan tongkol dapat diolah sebagai bahan lauk dan cemilan dengan rasa gurih dan menarik serta memiliki nilai gizi yang tinggi dan berkualitas.

Ikan tongkol (Euthynnus affinis) adalah ikan yang berpotensi cukup tinggi serta memiliki nilai 
ekonomis dan banyak disukai masyarakat (Sanger G, 2010). Menurut Arnenda dan Rochman (2019); Amri et al., (2018), Salah satu wilayah Indonesia sebagai penghasil utama dan habitat tongkol adalah Samudra Hindia di selatan Jawa sampai Nusa Tenggara yang merupakan batas selatan desa Batunampar selatan. Oleh karena daerah tangkapan dekat dengan desa maka ketersediaan tongkol selalu ada sepanjang tahun. Tongkol merupakan ikan yang memiliki gizi yang lengkap dan harganya terjangkau. Ikan tongkol memiliki kelebihan yaitu kandungan protein yang tinggi serta kaya akan asam lemak omega 3 dan setiap 100 gram mempunyai komposisi kimia yang tediri dari air $69,40 \%$, lemak $1,50 \%$, protein $25,00 \%$ dan karbohidrat 0,03\% (Sanger G, 2010) serta mengandung beberapa mineral seperti kalsium, fosfor, besi, sodium, vitamin A (retinol), dan vitamin B (thiamin, riboflavin dan niasin) (Hafiludin, 2011). Daging ikannya mudah dibuat untuk berbagai olahan baik lauk maupun cemilan, sehingga dianggap perlu diadakan pelatihan ibuibu dan remaja putri Desa Batunampar Selatan dalam mengolah ikan tonggkol menjadi makanan sehari-hari maupun cemilan.

Tujuan kegiatan ini adalah memberikan edukasi gizi ikan untuk meningkatkan gizi masyarakat desa Batunampar Selatan dan memberikan keterampilan membuat makanan olahan dari ikan tongkol untuk diversifikasi olahan hasil perikanan agar memperpanjang dayasimpanya itu dalam bentuk risoles dan tongkol presto.

\section{METODE KEGIATAN}

Penyuluhan dan pelatihan pengolahan ikan dengan bahan baku ikan tongkol dilakukan pada hari Jum'at tanggal 5 Agustus 2016. Penyuluhan dilakukan di balai desa Batunampar selatan.
Kegiatan penyuluhan dan pelatihan pengolahan ikan tongkol mengutamakan ibu-ibu rumah tangga dan remaja putri sebagai peserta namun tidak menutup peluang bila ada bapak-bapak atau remaja putra menghadiri.

Untuk meningkatan pengetahuan dan keterampilan kelompok masyarakat sasaran tentang aspek gizi ikan tongkol dan pengolahan .Maka dilakukan pelatihan terhadap kelompok masyarakat sasaran (ibu-ibu dan remaja putri). Materi pelatihan yang diberikan antara lain Gizi ikan tongkol, Pemilihan Bahan baku ikan dan pengolahan ikan tongkol. Pelatihan dilaksanakan dengan menggunakan metode Pendidikan Orang Dewasa (POD) dengan penekanan pada model komunikasi dua arah dengan pola tukar menukar pengalaman, diskusi kelompok, dan demonstrasi yang dilaksanakan dalam bentuk klasikal. Berikut langkah-langkah dalam pengolahan ikan tongkol.

1. Persiapan

- Memilih ikan tongkol yang masih segar ditandai oleh insang merah, daging masih kenyal dan mata bening

- Menyiapkan bumbu-bumbu dan alat presto

2. Pembumbuan

- Menyiangi ikan dan dicuci

- Menghaluskan bumbu; 20 btr b.merah; 10 btr b.putih; 2 ruas jari kunyit; 2 ruas jari jahe; 15 btr kemiri sangrai; $2 \mathrm{sdm}$ garam.

- Tata serai dan daun salam di dasar sarinngan panci presto

- Melumuri ikan tongkol dengan setengah bagian bumbu halus dan ragi instant, diamkan selama 2 jam dalam presto

3. Pemasakan

- Memasak ikan tongkol bumbu selama 2 jam setelah mendesis.

4. penyajian

- Bisa disajikan dengan digoreng atau diolah dengan cara lain

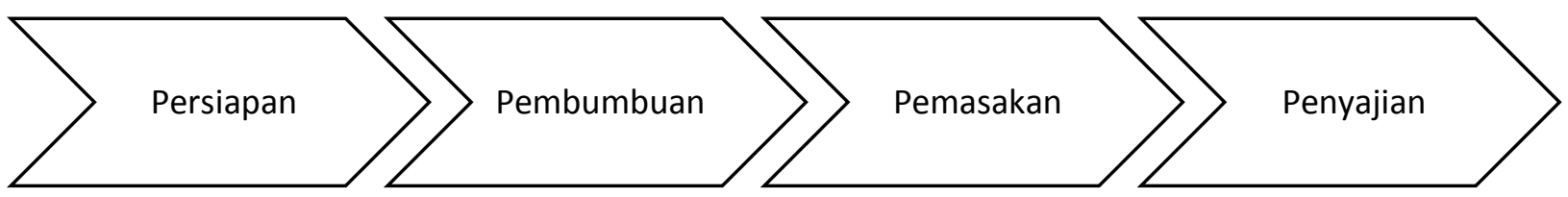

Gambar 1. Diagram alir proses pembuatan tongkol presto 


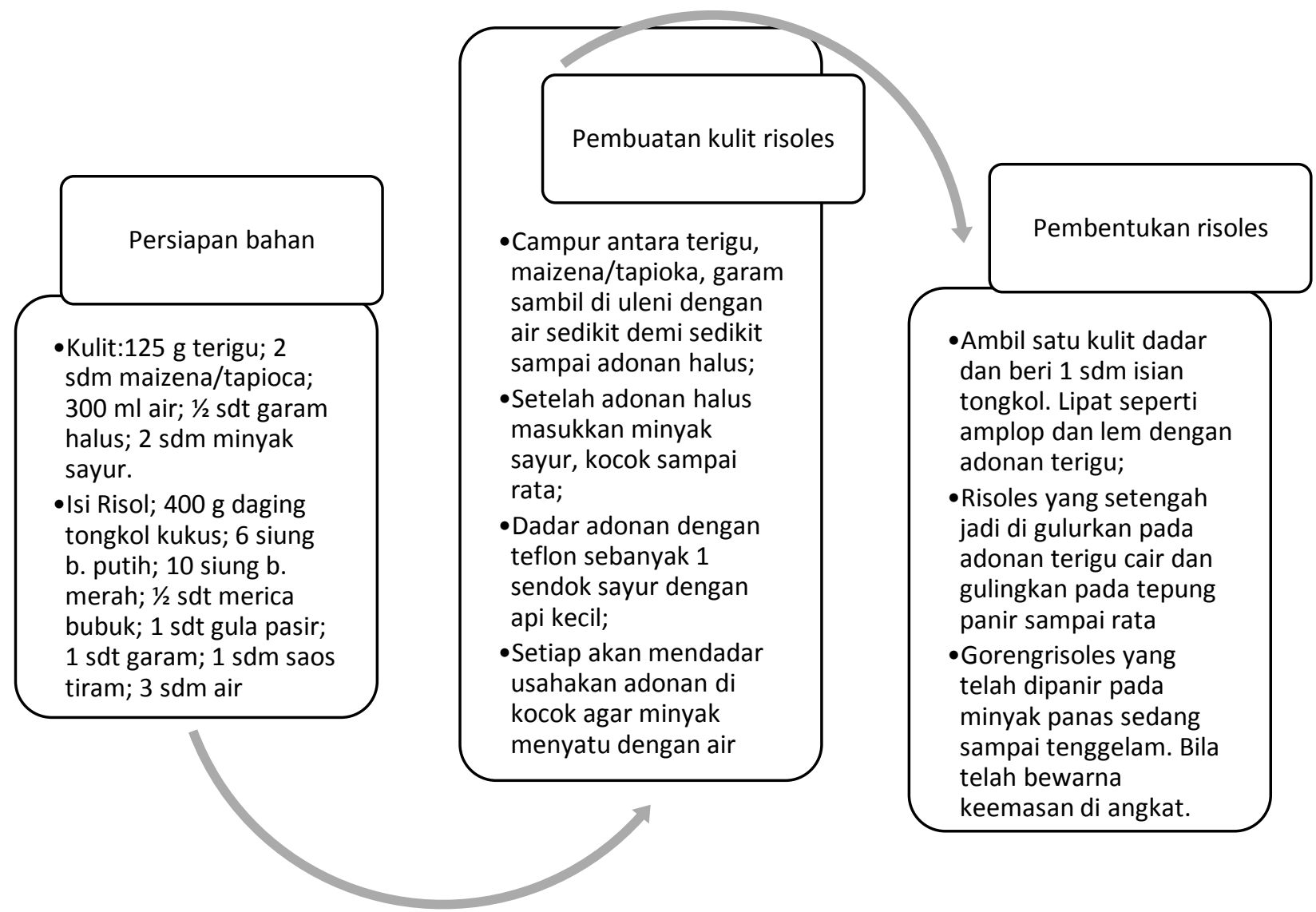

Gambar 2. Alur pembuatan risoles tongkol

\section{HASIL DAN PEMBAHASAN}

Peserta kegiatan ini sebanyak 28 orang yang terdiri dari ibu-ibu dan remaja putri (Gambar 3 dan 4). Ibu rumah tangga memiliki peran utama dalam mengatur gizi rumah tangga, sehingga mereka merupakan target utama kegiatan ini, sedangkan remaja putri merupakan calon ibu rumah tangga dan mereka kerap membantu ibu rumah tangga dalam menyiapkan makanan di setiap rumah tangga. Selain itu remaja putri harus tahu juga pengetahuan tentang gizi karena banyak ditemukan remaja putri menderita kekurangan gizi berupa penyakit anemia (Restuti et al., 2016). Gizi di setiap rumah tangga dapat diperbaiki dengan peranan optimal seorang ibu dalam menyajikan makanan yang memiliki kandungan gizi dan vitamin yang komplek. Jika ibu memiliki pengetahuan yang baik tentang gizi balita, diharapkan ibu juga akan memiliki sikap dan perilaku yang baik pula dalam pemenuhan gizi balita. Pengetahuan ibu mengenai gizi akan berpengaruh terhadap hidangan dan mutu makanan yang disajikan untuk anggota keluarga termasuk balita. Sikap ibu dalam memenuhi kebutuhan gizi balita juga sangat penting. Sikap merupakan faktor yang memengaruhi perilaku kesehatan seseorang. Perubahan sikap secara berkelanjutan dapat memengaruhi perilaku seseorang, dimana perilaku pemenuhan gizi yang baik dapat meningkatkan status gizi anak (Setyaningsih dan Agustini, 2014). Ditambahkan pula oleh Yendi et al., 2017, dalam pengujian korelasi antara peran ibu dalam pemenuhan gizi anak dengan status gizi anak didapatkan hubungan yang signifikan adanya pengaruh peran ibu dalam pemenuhan gizi anak dengan status gizi anak disebabkan oleh proses belajar. Proses belajar akan mengarah pada pembentukan sikap dan tindakan tertentu. Hal ini dapat dimengerti bahwa semakin baik pengetahuan seseorang diharapkan sikap dan tindakan semakin baik juga dalam pemenuhan gizi anak. Makanan tersebut tidak harus berbahan baku mahal. Desa Batunampar selatan merupakan desa pantai sehingga masyarakat lebih mudah dalam mendapatkan ikan. 


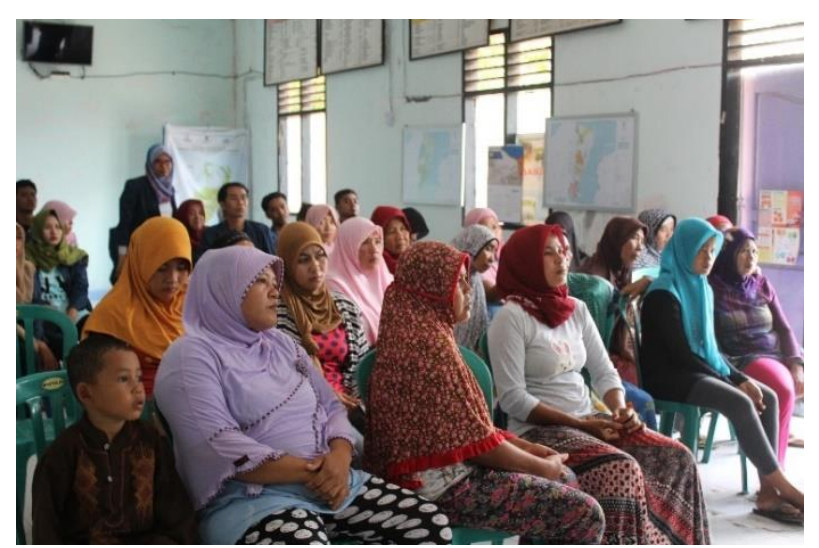

Gambar 3. Peserta kegiatan pengolahan ikan tongkol

Kegiatan dimulai dengan terlebih dahulu memberikan penjelasan nilai gizi ikan tongkol dan manfaat mengkonsumsi ikan. Ikan memiliki kandungan protein yang cukup tinggi dan vitamin yang lengkap. Ikan merupakan sumber alami asam lemak omega 3 yaitu eicosa pentaenoic acid (EPA) dan decosa hexaenoic acid (DHA) yang berfungsi untuk mencegahaterosklerosis. Omega 3 juga dapat menurunkan kadar trigliserida dalam darah,kadar kolesterol hati dan jantung. Kadar asam lemak omega 3 dalam beberapa jenis ikan laut di perairan Indonesia berkisar antara 0,1-0,5 $\mathrm{g} / 100 \mathrm{~g}$ daging ikan. Berdasarkan data yang telah dikeluarkan oleh Lembaga Gizi Departemen Kesehatan RI, beberapa jenis ikan laut Indonesia memiliki kandungan asam lemak omega 3 tinggi (sampai 10,9 g/100 g) seperti ikan sidat, terubuk, tenggiri, kembung, layang, bawal, seren, slengseng, tuna dan sebagainya (Surriawiria, 2002 dalam Hafiludin, 2011).

Ikan tongkol (Euthynnus affinis) merupakan spesies dari kelas Scromboidae seperti ikan tuna. Ikan tongkol memiliki kandungan protein yaitu antara 2,6-26,2 g/100 g daging, lemak antara 0,2-2,7 g/100 g daging, dan beberapa mineral (kalsium, fosfor, besi, sodium), vitamin A (retinol), dan vitamin B (thiamin, riboflavin dan niasin) (Departemen Kesehatan Republik Indonesia, 1995).

Olahan makanan yang dibuat adalah tongkol presto dan risoles tongkol. Ikan tongkol sendiri dapat di buat dalam bentuk olahan lain seperti nugget tongkol, rolade, sosis atau bakso yang juga digemari oleh balita dan anak-anak. Tongkol presto memiliki keunggulan disbanding ikan pondang biasa yaitu tulang ikan dapat dikonsumsi karena telah lunak sehingga kandungan kalsium yang baik untuk pertumbuhan anak-anak bisa tercukupi. Sedang untuk risoles akan bisa mencukupi karbohidrat, protein, lemak dan mineral dalam satu olahan. Karbohidrat didapat dari kulit risoles, lemak dari minyak dan protein dari daging ikan dan telur.

Kelemahan ikan tongkol sebagaimana yang juga dimiliki oleh komoditi hewani lainnya adalah bahwa dengan kandungan gizi seperti protein dan air yang cukup tinggi, maka memiliki sifat yang mudah busuk setelah ditangkap dan mati. Oleh karena itu perlu dilakukan usaha peningkatan daya simpan dan daya awet produk perikanan pada pasca panen meliputi proses pengawetan maupun pengolahan. Selain lezat dan bergizi,tongkol juga memiliki khasiat yang cukup spesifik, yaitu merangsang pertumbuhan sel-sel darah merah dan menghambat proses penuaan (Hastuti dan Ruhibnur, 2016).

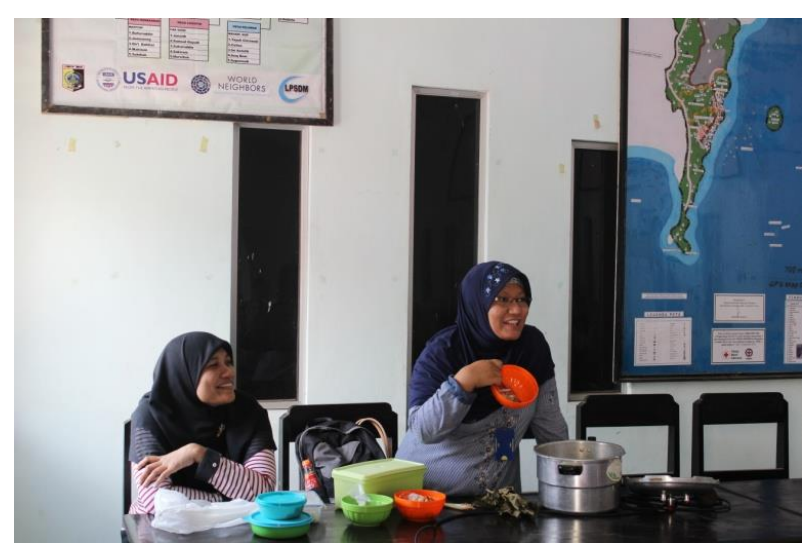

Gambar 4. Pelatihan pembuatan risoles dan presto tongkol

Tongkol presto dapat dihidangkan dengan sambal dan dapat juga diolah kembali menjadi masakan dalam bentuk lain missalnya tongkol presto balado. Cita rasa tongkol presto lebih enak dibanding dengan tongkol yang dikukus biasa maupun tongkol goreng sehingga anak-anak akan lebih tertarik untuk makan ikan dan dapat meningkatkan gizi anak serta anggota keluarga lainnya.

Saat pelatihan respon ibu-ibu dan remaja putrid sangat baik ini ditandai oleh banyaknya pertanyaan baik soal teknik pengolahan dan modifikasi resep. Contoh pertanyaan saat seorang ibu bertanya apakah bisa penggunaan ikan tongkol 
diganti dengan jenis ikan yang lain. Resep yang diberikan merupakan resep dasar sehingga modifikasi bahan utama mudah dilakukan.

\section{KESIMPULAN DAN SARAN}

\section{Kesimpulan}

Edukasi gizi ikan, pentingnya makan ikan dan keterampilan membuat risoles dan presto tongkol telah diberikan kepada ibu rumah tangga dan remaja putri Desa Batunampar Selatan dan mereka telah paham keunggulan ikan dibanding sumber protein hewani lain. Ibu-ibu dan remaja putri juga telah bisa mengolah ikan tongkol menjadi presto dan risoles. Penggunaan ikan tongkol bisa diganti dengan ikan yang diinginkan dan tersedia.

\section{Saran}

Diharapkan pada saat pelaksanaan pelatihan ditentukan waktu yang memang waktu senggang ibu-ibu dan remaja putri serta adanya partisipasi peserta pelatihan dengan membawa alat masingmasing sehingga pelatihan berjalan lancar.

\section{UCAPAN TERIMA KASIH}

Ucapan terima kasih disampaikan kepada Kemenristekdikti yang memberikan dana untuk kegiatan ini sebagai bagian dari kegiatan KKN PPM.

\section{DAFTAR PUSTAKA}

Amri K., F.A.Nora., D. Ernaningsih., T.Hidayat. 2018. Reproduksi Dan Musim Pemijahan Tongkol Komo (Euthynnus Affinis) Berdasarkan Monsun Dan Suhu Permukaan Laut Di Samudera Hindia selatan Jawa-Nusa Tenggara. Bawal;10(2);155-167.

Anonim, 2002. Profil Desa Batunampar. Pemerintah Desa Batunampar. Jerowaru. Lombok Timur Nusa Tenggara Barat.

Arnenda, G.V., F. Rochman. 2019. Sebaran Daerah Penangkapan Dan Potensi Stok Sumber Daya Ikan Tuna Tongkol Cakalang Di Labuhan Lombok. Prosiding Seminar Nasional Tahunan XVI Hasil Penelitian Perikanan dan
Kelautan Universitas Gajah Mada. Hal 274282.

Cokrowati, N., M. Junaidi, DN. Setyowati, N. Diniarti. 2016. Perbaikan Sistem budidaya Karamba Jaring Apung dengan Sistem Terintegrasi. Jurnal Abdi Insani; 3 (2); 67-71.

Departemen Kesehatan Republik Indonesia. 1995. Materia Medika Indonesia. Jakarta. Departemen Kesehatan Republik Indonesia.

Hafiludin. 2011. Karakteristik Prosimat dan Kandungan Senyawa Kimia Daging Putih dan Daging Merah Ikan Tongkol (Euthynnus affinis). Jurnal Kelautan; 4(1);1-10.

Hastuti, N.D., R. Ruhibnur. 2016. Nugget dan Kerupuk Ikan tongkol sebagai alternative usaha untuk meningkatkan pendapatan masyarakat. Agromix;9 (1); 76-81.

Kabupaten Lombok Timur, 2001. Peraturan Daerah (PERDA) Kabupaten Lombok Timur.SelongKabupaten Lombok Timur. Provinsi Nusa Tenggara Barat.

Restuti, A.N., N.M. Rosiana., A.Febriyatna. 2016. Rolade Ikan Tongkol Sebagai Alternative Kudapan Bagi Remaja Putrid Anemia. Prosiding Seminar Hasil Penelitian dan Pengabdian Masyarakat Dana BOPTN tahun 2016. ISBN:978-602-14917-3-7. Hal 236-240.

Sanger G. 2010. Mutu Kesegaran Ikan Tongkol (Auxis tazard) selama Penyimpanan Dingin. Warta WIPTEK;35(1);39-43.

Setyaningsih, S.R., N. Agustini. 2014. Pengetahuan, Sikap dan Tingkah Laku Ibu dalam Pemenuhan Gizi Balita: sebuah Survai. Jurnal Keperawatan Indonesia;17(3);88-94.

Tanziha, Ikeu. 2009. Goal Programming:Optimalisasi Konsumsi Pangan Balita Pada Keluarga Nelayan. Jurnal Gizi dan Pangan; 4(1):1-7.

Yendi, Y.D.N., N.L.P. Eka, N. Maemunah. 2017. Hubungan Antara Peran Ibu Dalam Pemenuhan Gizi Anak Dengan Status Gizi Anak Prasekolah Di TK Dharma Wanita Persatuan 2 Tlogomas Kota Malang. Nursing News;2(2);761-771. 